\title{
Management of Biohazards and Pandemics: COVID-19 and Its Implications in the Construction Sector
}

\author{
Chiemela Victor Amaechi1,2* (D), Ebube Charles Amaechi ${ }^{3}{ }^{(0)}$, Sharon Chinyere Amechi ${ }^{4,5}$, \\ Abiodun Kolawole Oyetunji6,7 (1), Irish Mpho Kgosiemang8, Okechukwu John Mgbeoji ${ }^{9}$, \\ Adesola Samson 0jo ${ }^{6}$, Alejandro Moure Abelenda ${ }^{1,6}{ }^{(0)}$, Mohamed Milad1 ${ }^{(\mathbb{C})}$, Ibitoye Adelusi ${ }^{1}$ (D), \\ Akinwale Oladotun Coker10 (1)
}

\author{
${ }^{1}$ Department of Engineering, Lancaster University, Lancaster, UK \\ ${ }^{2}$ Standards Organisation of Nigeria (SON), Abuja, Nigeria \\ ${ }^{3}$ Department of Zoology, University of Ilorin, Ilorin, Kwara State, Nigeria \\ ${ }^{4}$ School of Health and Social Wellbeing, University of the West of England (UWE), Bristol, UK \\ ${ }^{5}$ Department of Radiography, Federal Medical Centre, Asaba, Delta State, Nigeria \\ ${ }^{6}$ Lancaster Environment Centre (LEC), Lancaster University, Lancaster, Lancashire, UK \\ ${ }^{7}$ Department of Estate Management, University of Benin, Benin City, Edo State, Nigeria \\ ${ }^{8}$ Department of Business Management, University of Central Lancashire (UCLAN), Preston, Lancashire, UK \\ ${ }^{9} \mathrm{X}$-Ray Unit, Seventh-Day Adventist Hospital and Motherless Babies' Home, Ogbor Hill, Aba, Abia State, Nigeria \\ ${ }^{10}$ Department of Civil Engineering, University of Ibadan, Ibadan, Oyo State, Nigeria \\ Email: *c.amaechi@lancaster.ac.uk, *chiemelavic@gmail.com, ebubeamechi@yahoo.com, sharon2u45@yahoo.co.uk, \\ a.oyetunji@lancaster.ac.uk, ikgosiemang@hotmail.com, okechukwu.mgbeoji@yahoo.com, samsonojo@yahoo.com, \\ a.moureabelenda@lancaster.ac.uk,m.milad@lancaster.ac.uk, ibitoyea@hotmail.com,cokerwale@yahoo.com
}

How to cite this paper: Amaechi, C.V., Amaechi, E.C., Amechi, S.C., Oyetunji, A.K., Kgosiemang, I.M., Mgbeoji, O.J., Ojo, A.S., Abelenda, A.M., Milad, M., Adelusi, I. and Coker, A.O. (2022) Management of Biohazards and Pandemics: COVID-19 and Its Implications in the Construction Sector. Computational Water, Energy, and Environmental Engineering, 11, 34-63. https://doi.org/10.4236/cweee.2022.111003

Received: December 28, 2021

Accepted: January 25, 2022

Published: January 28, 2022

Copyright $\odot 2022$ by author(s) and Scientific Research Publishing Inc. This work is licensed under the Creative Commons Attribution International License (CC BY 4.0).

\begin{abstract}
This paper investigates the impact of biohazards and pandemics on construction workers' health and well-being. A proper selection of control methods for biohazards and pandemics like COVID-19 pandemic will result in improved public health conditions. Occupational risks in the construction industry are also examined, with a focus on biohazards and pandemics, their containment, and the implications for health and safety. A safer work environment in the construction industry is encouraged. In this study, some statistical methods were used to analyse the data obtained from sampled questionnaire. According to the findings, fewer people in poor developing countries get routine check-ups compared to developed countries. The construction industries studied have little or no insurance plans for staff. It also demonstrates that personal protective equipment (PPE) such as nasal masks, helmets, hand gloves, and work aprons can assist in the control of biohazards in the construction sector, such as asthma, cancer, and asbestosis. There should be safety awareness programmes, conferences, and seminars, as well as
\end{abstract}


http://creativecommons.org/licenses/by/4.0/ (c) (i) Open Access first-aid kits and HSE and qualified health workers on all building sites. In addition, the government should examine the site for the usage of PPEs and verify that records of family/personal medical history are maintained.

\section{Keywords}

Pandemic, Biohazard, Biological Hazard, Biohazard Control, Construction, COVID19, Corona Virus, SARS-CoV, Hazard, Health and Safety, Personal Protective Equipment (PPE)

\section{Introduction}

Controlling biohazards and pandemics in the construction sector is a critical issue that has piqued the interest of public health, environmental engineering, and civil engineering professionals. Despite the wide range of environmental professionals, there is still a challenge in containing the current Corona Virus pandemic in COVID-19 from 2019 to 2021 [1] [2] [3] [4]. However, the control cuts across from the pandemic era to the post-pandemic era [5] [6] [7]. The pandemic has also been noted to have affected the educational system globally [8], specialised workplace attitudes and general mental health [9], and crisis-driven governance of the populace [10] [11]. Despite that it has also affected the globe, there have been some progress made by various disease control organisations over the years. These lessons learnt include other epidemics and pandemics ranging from SARS COV-2, Ebola Virus to COVID19 pandemic [12] [13] [14] [15]. There are also environmental concerns that are related to pollution of plastics from disposed nose marks, and face shields during COVID19 pandemic era [16] [17]. There are also concerns that these plastic wastes are harmful to the ecosystem [18] [19] [20] [21]. As such, both the environmentalist and the environmental engineer are tasked with resolving various environmental issues. These issues include atmospheric pollution, the control of water, soil, environmental sanitation and the social and environmental impact of these solutions. Based on the management aspect, these include the control of pandemics, the control of arthropod-borne diseases, the elimination of industrial health hazards, and the effect of technological advances on the environment. Different researchers have recommended that some policy protocols be considered in the construction industry for both biohazards and pandemics like COVID19 using nose masks [22] [23] [24].

Generally, the engineers are concerned with the challenges, concepts, awareness, utility, management of engineering facilities and development of new technologies [25] [26] [27] [28]. These technologies are used to develop construction materials like pipes and hoses [29] [30] [31] [32] as well as 3D-printed face shields [33] [34] [35]. During the pandemic, the engineers were tasked with developing innovative solutions such as additive manufactured face shields [36] [37], incubators [38] [39] and other assistive technologies [40] [41] [42]. Also, 
new techniques have also been developed by bio-engineers based on COVID19 [43] [44]. However, these developments have increased the issues such as plastic wastes and electronic wastes in the environment [45] [46] [47]. Thus, proper waste disposal, waste control and recycling attitudes [47] [48] [49] are recommended in the pre and post COVID19 pandemic era. Having a solid public health of the populace is every nation's most valuable asset, and it is the basis upon which the people's whole production capacity is built [50]. Over a decade ago, Essenberg [51], reported that about 180,000 workers die and 110 million are injured in workplace accidents each year, but this has decreased in recent times. Occupational health and safety is well structured in developed nations. However, in developing countries, it is on the average, substantially worse than in developed countries [50]. According to Seagle [52], this is due to a lack of resources in the context of an economic downturn, the implementation of remedial and preventative actions to improve occupational safety and health, and management's attitude toward worker health and safety [53] [54] [55]. Construction workers are exposed to a variety of health and safety hazards. These could include exposure to materials that can cause serious sickness and have a long-term effect on the worker's health. This study aims to raise awareness about the potential biological risks of several common materials that construction workers may come into contact with on the job. Large wood dust particles, for example, can readily become stuck in the nasal canal and are known to cause nasal cancer in woodworkers. Figure 1 shows the route of entry of biohazards in the human body. Inhaling wood dust reduces lung function, which leads to chronic lung illness. Solvents, like other chemicals, may be utilised in a variety of construction-related

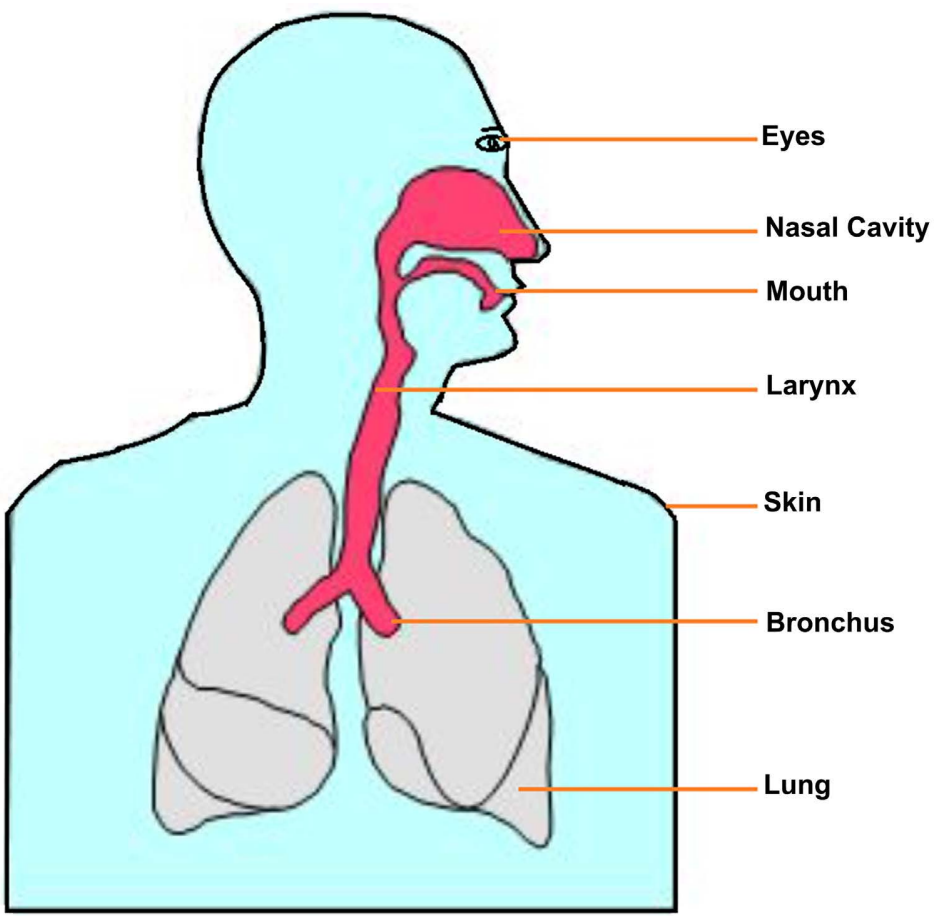

Figure 1. Route of entry of biohazards in the human body. 
operations. Furthermore, asbestosis is a lung defect caused by exposure to a dusty environment, particularly in harsh weather or at an asbestos production factory. Solvents evaporate quickly. Exposure to liquid or vapour forms can have both long-term and short-term health consequences for workers. The health effects will be mostly determined by the chemical in the solvent and the amount of time spent in contact with it. Solvents are primarily inhaled, however they can also be absorbed through the skin. Short-term solvent exposure can result in headaches, nausea, sleepiness, and dermatitis. A worker's kidneys, liver, and skin may be permanently damaged if they are exposed to a solvent on a regular basis. Solvent exposure can cause personality changes, sleep difficulties, short-term memory loss, and dementia, and the toxic effects on the neurological system are a major worry. By definition, a hazard is a situation that offers a risk to life, health, property, or the environment. Chemical Hazards, Biological Hazards, Environmental Hazards, Health Hazards, Natural Hazards, Fire Hazards, and Workplace Hazards are the broad categories of hazards. However, the focus of this study will be on biological risks. An organism, or a chemical derived from an organism, that poses a threat to (mainly) human health is referred to as a biological hazard or biohazard [56]-[63]. Biohazards are samples of microorganisms, viruses, or toxins (from a biological source) that can pose a threat to human or harm the human health. They could also arise from medical wastes or other trash dumps and it may also contain compounds that are toxic to animals [64]-[69]. Rodents, insects, bacteria, viruses, moulds, yeasts, and fungi are examples of biological risks. Infections, allergies, and poisoning can all be caused by them [70]. A proper understanding of biohazards and pandemics by the public as well as political leaders is required for effective control against the damage caused by biohazards. Biohazards can be managed at the source (engineering control), from the source to the worker, and at the workplace (environmental control) [71]-[79].

This paper explores the management of biohazards and pandemics in the construction industry, taking Ibadan as a case study. Section 1 introduces the concept of biohazards and pandemics. Section 2 presents the materials and methods for the study. Section 3 presents the results while Section 4 discusses the results. Section 5 presents some policy implications while Section 6 presents the concluding remarks. The main objectives are to identify potential biohazards and pandemics like COVID-19 pandemic having Corona Virus as a current global concern. Also, the study identifies preventive actions to be taken and to selects appropriate control measures for biohazards and pandemics to promote higher quality of health and safety, as well as safer worksites in the construction industry.

\section{Data and Sampling Methods}

\subsection{Data Description}

The study used questionnaires and covered a wide range of topics, including the 
many strategies for issues of pandemics, controlling biological risks, their applications, and comparisons with other studies in the field; it also compared data acquired through tables, bar charts, and pie charts. Simple frequencies and descriptive statistical methods were used to tabulate, run, and analyse the data obtained from the questionnaire. There is a problem in developing countries since developed countries' health is better than developing countries', and this also extends to the construction industry in developing countries. Using a main city in Nigeria to be the case study from a developing nation, this research found that fewer people have routinely conducted check-ups. In addition, almost all of the examined construction industries have little or no insurance policies. However, this is typical of some construction sites in underdeveloped and developing nations.

\subsection{Study Area}

The scope of this study was limited to biohazards in the construction industry. On the case study, the steps taken include data collection, sites examination, and analysis of the results. No construction work was undertaken. The area of study will be Ibadan, the capital of Oyo State, Nigeria. The management of biological hazards in construction industry was conducted by using a case study of Ibadan. Figure 2 shows the map of Nigeria, showing Ibadan as one of her main cities. Ibadan as a main city in Nigeria is densely populated, has good road networks, as seen in Figure 3. It has good rail network and a large city by geographical area. Ibadan is the third-largest city by population in Nigeria after Lagos and Kano, with a total population of 3,649,000 as of 2021, and over 6 million people within its metropolitan area. Ibadan is an ancient capital city and one of the largest metropolises in West Africa. There are a number of registered construction firms in Ibadan. Since the registered construction companies are both local and international, collecting required information from all available construction companies was a challenge.

\subsection{Sample Study}

This research was carried out under the auspices of engineering and environmental control. The experimental research design was used to carry out the research control of biological hazards in the construction sector, with a case study in Ibadan as a case study. An in-depth investigation of one environment is a deep exploratory account of an individual, a group, or an organisation in a case study research design. The questionnaires are being prepared and distributed at various building sites in Ibadan. The information is acquired and analysed. In summary, the technique included a field survey, site observation and note-taking (as needed), photographing of noteworthy events, questionnaire administration, and data analysis. Questionnaires were used to fill out, collect, evaluate, and compare the results with those of highly-industrialised countries such as the U.K. 


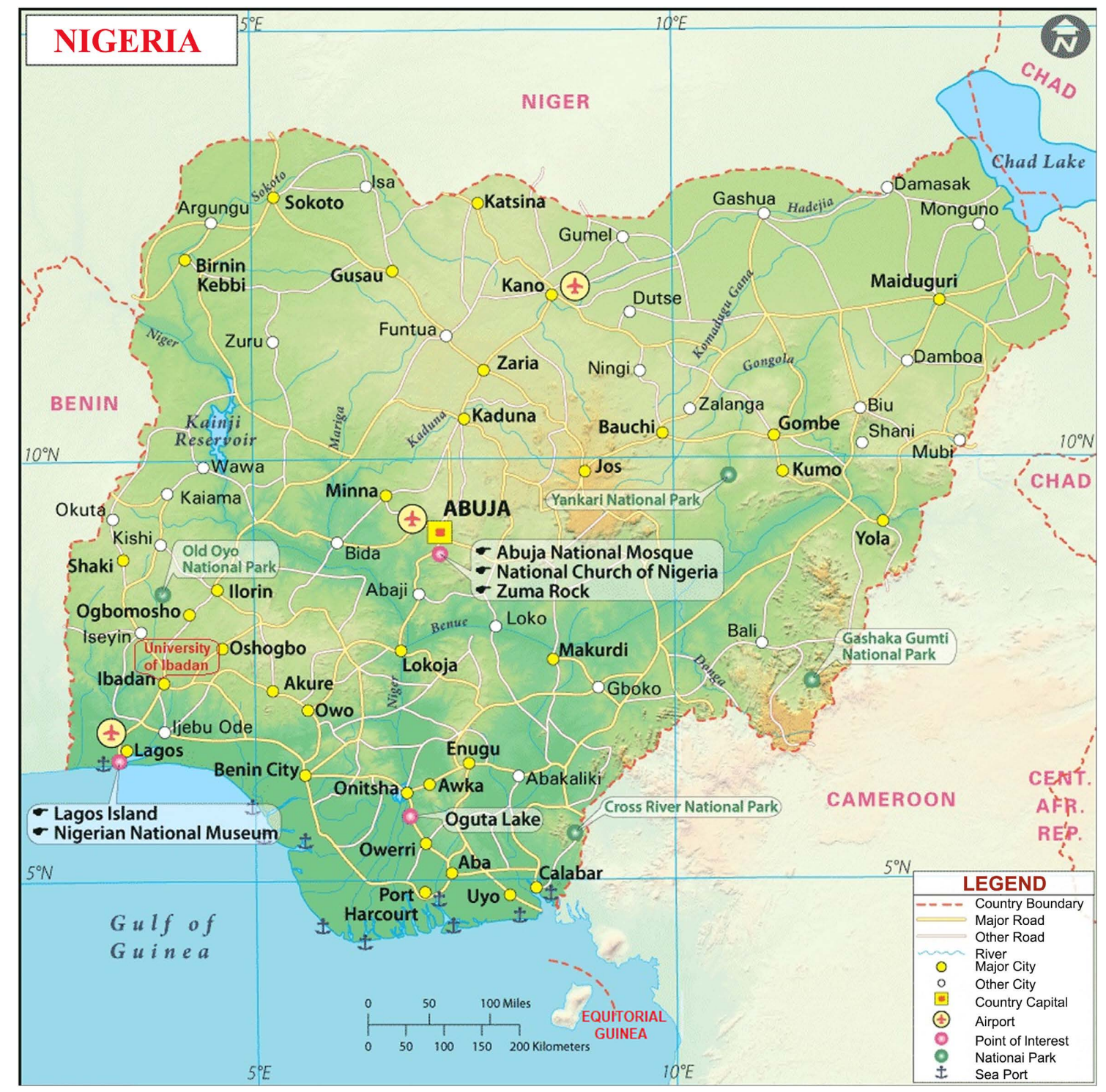

Figure 2. Map of Nigeria showing location of main cities like Ibadan.

\subsection{Data Collation}

The data collation was carried out by using only data from the construction sites. It should be noted that wastes are also generated from both educational institutions, and hospital waste. However, these were not in the scope of this study as its is focused on the construction sector, although hospital wastes particularly are vulnerable to biohazards. In the building sites sampled in Ibadan, Oyo State, there were forty (40) questionnaires administered. The questionnaire is broken down into five sections: Health and Welfare, Biological Hazards, Biohazard Controls, Occupational Health Data and Surveillance, and Other Ways to Protect/safeguard Health.

\subsection{Data Analysis}

The statistical analysis of the processed questionnaires that were interpreted into 

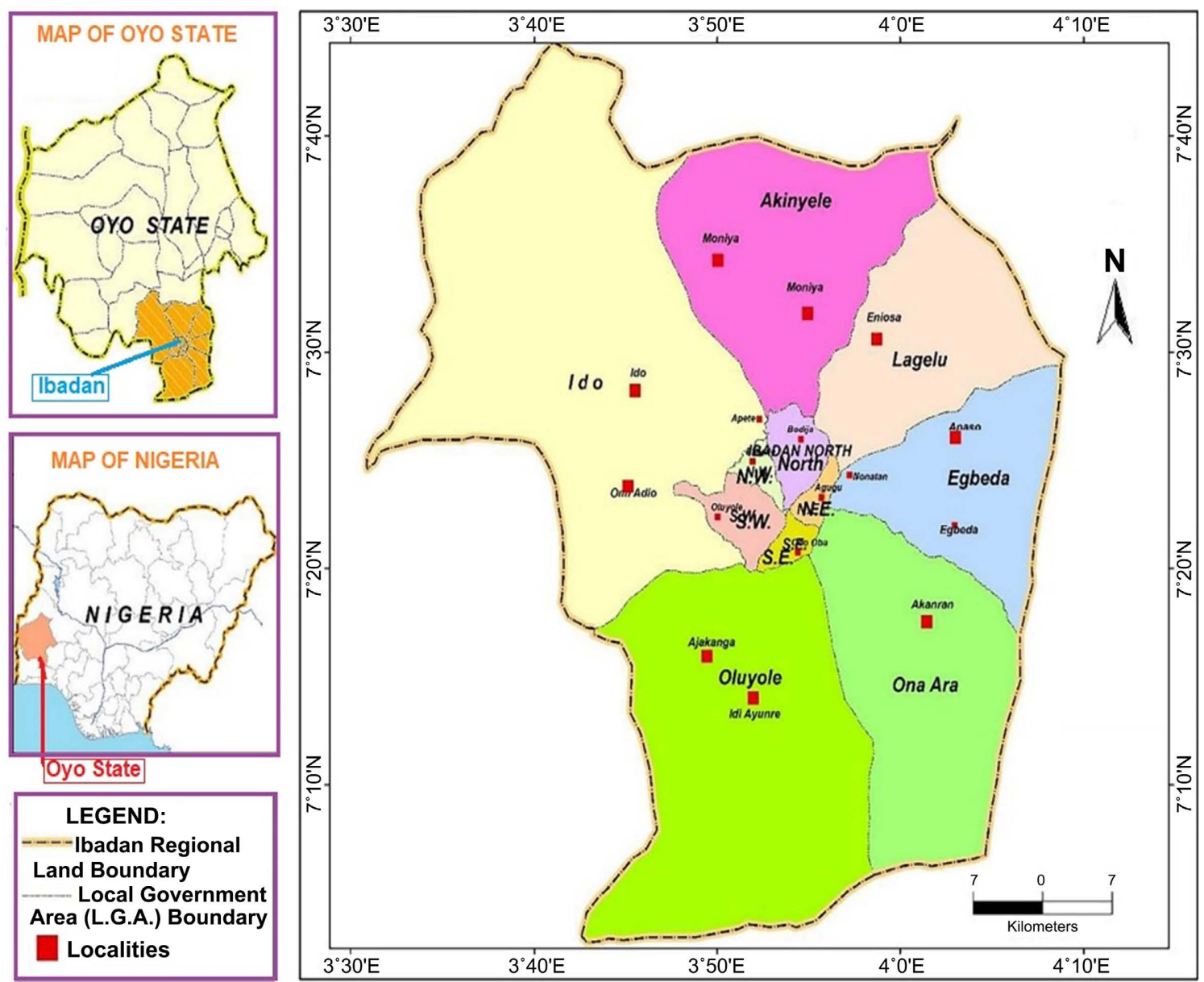

Figure 3. Map of Ibadan, Oyo State, Nigeria showing localities in Ibadan.

tables was done utilising a bar chart and statistical index. The results and discussion of data were obtained from the bar chart and statistical index, from which the summary, conclusion, and recommendation were produced. Statistical analysis tools were utilised in SPSS version 17 to conduct the analysis. The data could come from a secondary or primary source. Secondary data are second-hand information, i.e., data that has been collected and given in a specific format, whereas primary data is first-hand information that is required in research to supplement the secondary data found.

The primary source of data for this research was site observation, interviews, and the administration of questionnaires on the control of biological hazards in the construction sector. Before conducting the primary research, the questionnaire was prepared and pre-tested two (2) months earlier in certain construction enterprises in the Ibadan metropolitan to determine its usability, validity, and reliability. The pre-testing involved a small group of participants who completed twenty (20) questionnaires and shared similar engineering features. From this respondent's data, it was possible to determine the trend in response to items, whether the respondents comprehended the items, and the length of time it might take to respond to the questionnaire during the pre-testing stage. 
The study's findings demonstrate that personal protective equipment (PPE) such as hand gloves, helmets, nasal masks, eye goggles, and work aprons can help prevent the spread of pandemics and biohazards in the construction industry, such as coronavirus, asthma, cancer, and asbestosis. There should be safety awareness programmes, conferences, and seminars, as well as first-aid kits and HSE and qualified health workers on all building sites. A complete personal and family medical history should be provided. Finally, the government should inspect the location for the use of personal protective equipment. The findings of this study are detailed in Section 3. Some recommendations on COVID-19 control were also drawn from this study.

\section{Results}

During the course of this study, researchers visited a number of construction sites in Oyo State where some construction activities were underway at the time of the data collation. Photographs were taken at a few of the locations. The site engineers were asked how they manage biological threats on their properties. The response showed that they were in charge of biohazards in general, but that not everyone was aware of them. Table 1 shows the results of the survey. It can be observed that site safety by the usage of muster points has the highest adherence of $88.57 \%$, while the lack of insurance and the lack of routine health checks was the least at $37.14 \%$. These findings will be detailed in Sections $3.1-3.12$.

The questionnaires were given to three different types of businesses: small, medium, and large. Highway, building, water/environmental, geotechnics, and other specialisations were among the companies examined (antenna erection, mast installation, metal fabrication, dam construction, and quarry sites). Building operations were reported as the main type of construction work by $37.14 \%$,

Table 1. Data for summary of survey of questionnaire responses.

\begin{tabular}{lccccc}
\hline \multicolumn{1}{c}{ Parameters } & $\begin{array}{c}\text { No. of } \\
\text { YES }\end{array}$ & $\begin{array}{c}\text { No. of } \\
\text { NO }\end{array}$ & Yes (\%) & No (\%) & $\begin{array}{c}\text { TOTAL } \\
(\%)\end{array}$ \\
\hline Have First-Aid Box on site & 22 & 13 & 62.86 & 37.14 & 100 \\
Had workers exposed to biohazard & 15 & 20 & 42.86 & 57.14 & 100 \\
Use of Muster Points/Signs & 31 & 4 & 88.57 & 11.43 & 100 \\
Use of PPEs & 23 & 12 & 65.71 & 34.29 & 100 \\
Have toilet/bathroom facilities & 20 & 15 & 57.14 & 42.86 & 100 \\
Have insurance policies & 13 & 22 & 37.14 & 62.86 & 100 \\
Organise seminars and workers & 21 & 14 & 60.00 & 40.00 & 100 \\
Ensure routine check-up & 13 & 22 & 37.14 & 62.86 & 100 \\
Ensure standard rules on site & 26 & 9 & 74.29 & 25.71 & 100 \\
Had compensated affected workers & 19 & 16 & 54.29 & 45.71 & 100 \\
Have HSE Personnels & 15 & 20 & 42.86 & 57.14 & 100 \\
\hline
\end{tabular}


closely followed by highway activities at $34.29 \%$. This is depicted in detail in Table 2, Figure 4 and Figure 5.

The construction industry involves both the civil engineers and the service engineers-mechanical, electrical and environmental engineers. While the civil engineering discipline includes highway, building, water/environmental, geotechnics, and other operations, environmental engineering now includes aspects of public health, landscaping, and drainage control. Every construction company has employees; the number of employees or the size of the workforce in a construction company is the population size of the company. For the sake of this analysis, ranges 1 - 50 are considered small, 51 - 149 are considered medium, and ranges between 150 and more are considered large. According to the responses to questionnaires about the size of their firms showed that $60 \%$ are small businesses, $25.71 \%$ are medium businesses, and $14.29 \%$ are large businesses (see Table 3, Figure 6 and Figure 7).

Table 2. Responses from construction firms that conduct seminars/workshop.

\begin{tabular}{cccccc}
\hline GEOTECHNICS & WATER/ENV. & BUILDING & HIGHWAY & OTHERS & TOTAL \\
\hline 3 & 5 & 13 & 12 & 2 & 35 \\
$8.57 \%$ & $14.29 \%$ & $37.14 \%$ & $4.29 \%$ & $5.71 \%$ & $100 \%$ \\
\hline
\end{tabular}

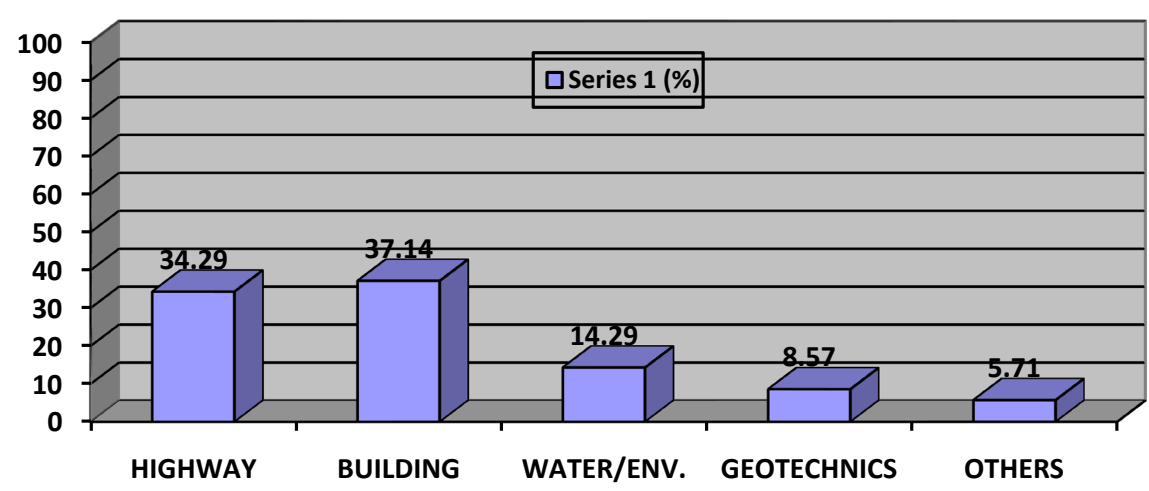

Figure 4. Responses of construction firms to questionnaires.

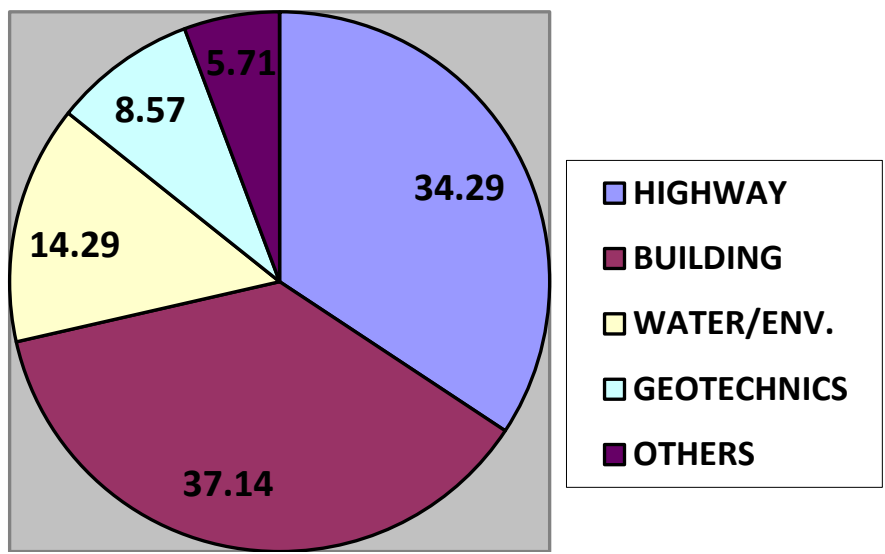

Figure 5. Pie chart of percentage responses to questionnaires. 
Table 3. Responses on sizes of construction firms.

\begin{tabular}{cccc}
\hline LARGE & MEDIUM & SMALL & TOTAL \\
\hline 5 & 9 & 21 & 35 \\
$14.29 \%$ & $25.71 \%$ & $60 \%$ & $100 \%$ \\
\hline
\end{tabular}

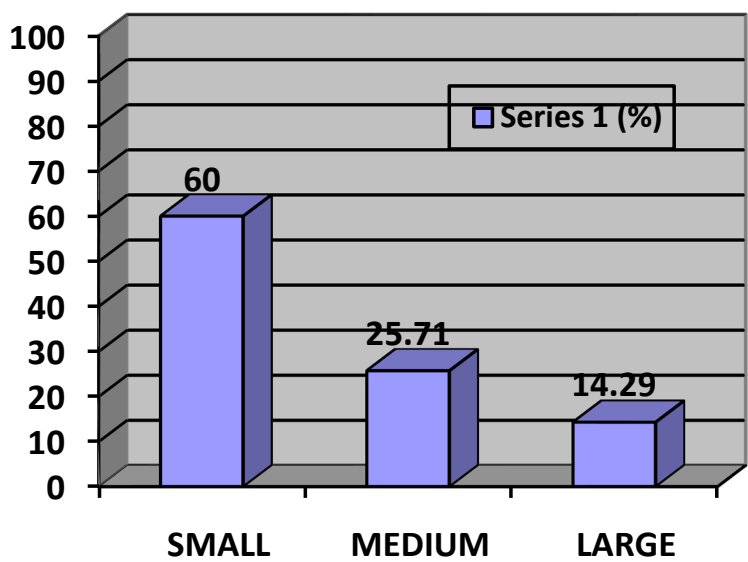

Figure 6. Responses on sizes of construction firms.

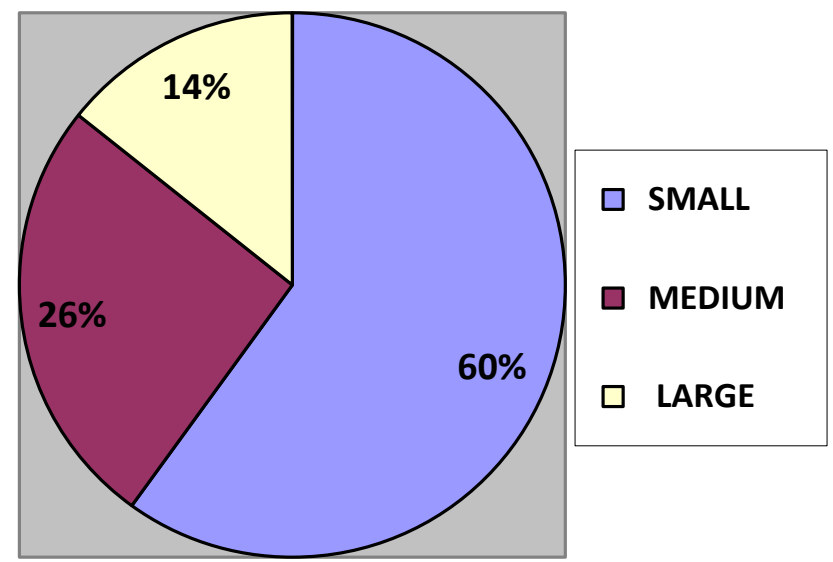

Figure 7. Responses on sizes of construction firms (Pie chart).

\subsection{Construction Firms That Ensure Availability and Functionality of Muster Points or Warning Sign-Posts}

In construction, every engineering activity should ensure safety first and have muster sites, warning signs, and an effective danger communication approach because safety is paramount. Table 4 and Figure 8 show that the majority of construction enterprises had warning signs and muster points to control dangers, with $88.57 \%$ of respondents stated in the affirmative "yes".

\subsection{Construction Firms with PPE-Conforming Workers}

The utilisation of Personal Protective Equipment (PPE) and protective clothes are critical in the construction industry. Depending on the sort of construction activity, this may include nasal masks, hand gloves, work aprons, helmets, and 
Table 4. Responses on construction firms with muster points/warning signs.

\begin{tabular}{ccc}
\hline YES & NO & TOTAL \\
\hline 31 & 4 & 35 \\
$88.57 \%$ & $11.43 \%$ & $100 \%$ \\
\hline
\end{tabular}

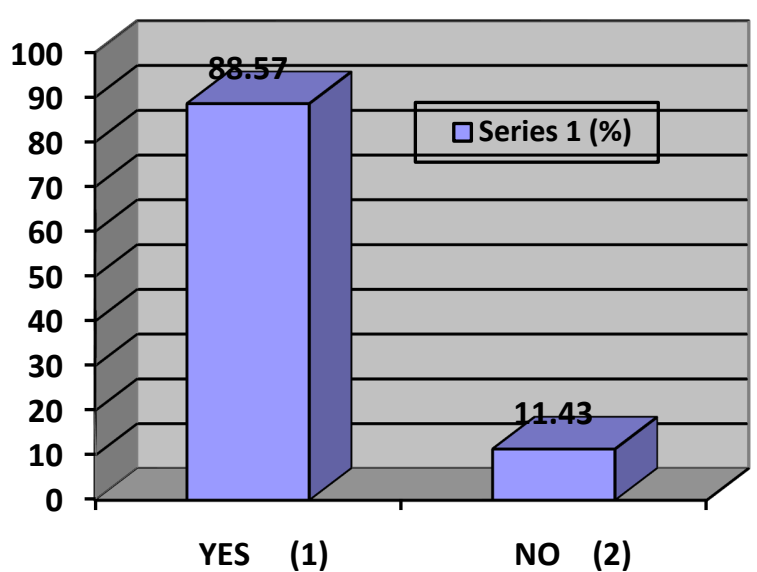

Figure 8. Responses on construction firms with muster points/warning signs.

goggles. The percentage response to the usage of PPEs is $65.71 \%$, as shown in Table 5 and Figure 9.

\subsection{Construction Firms with Projects Using HSE/Trained Health Personnels}

Some construction businesses strive to save money by not hiring Health and Safety Executives (HSE) and skilled health experts such as nurses, safety officers and doctors on site, which may be putting the lives of their workers in risk. The percentage response to the use of PPEs is $42.86 \%$ in Table 6 and Figure 10, which is not acceptable because there should be higher use of PPEs than this.

\subsection{Responses on Construction Firms Having First-Aid Box on Site}

In the event of an emergency, the first-aid kit is quite useful. This is also critical on all construction sites, as some biohazards, such as asthma, are fast-acting and life-threatening. The percentage of construction firms that have a first-aid box on site is $62.86 \%$, as shown in Table 7 and Figure 11 . This also demonstrates that not every construction firm has a first-aid box on site.

\subsection{Responses of Construction Firms That Do Routine Check-Up}

It is paramount that public health concerns like pandemics and biohazards are controlled. As the popular saying goes, "health is wealth." Workers should be checked on a regular basis, as this is critical in the construction industry's biohazard control. Table 8 and Figure 12 reveal that the percentage of construction firms that have a routine check-up is just $37.14 \%$, which should be higher and improvements made on it. 
Table 5. Percentage responses of construction companies that wear PPEs.

\begin{tabular}{ccc}
\hline YES & NO & TOTAL \\
\hline 23 & 12 & 35 \\
$65.71 \%$ & $34.29 \%$ & $100 \%$ \\
\hline
\end{tabular}

Table 6. Responses on construction firms that execute projects with HSE personnels or/and trained health personnels.

\begin{tabular}{ccc}
\hline YES & NO & TOTAL \\
\hline 15 & 20 & 35 \\
$42.86 \%$ & $57.14 \%$ & $100 \%$ \\
\hline
\end{tabular}

Table 7. Responses on construction firms having first-aid box.

\begin{tabular}{ccc}
\hline YES & NO & TOTAL \\
\hline 22 & & 35 \\
$62.86 \%$ & 13 & $100 \%$ \\
\hline
\end{tabular}

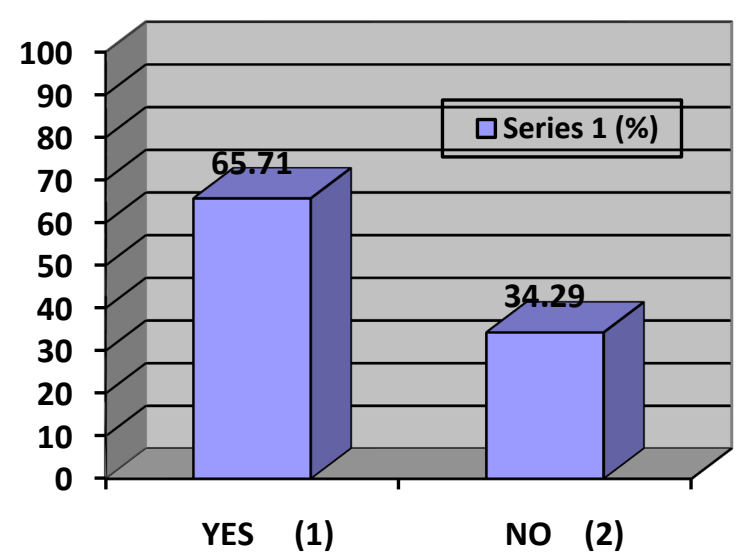

Figure 9. Percentage responses of construction companies that wear PPEs.

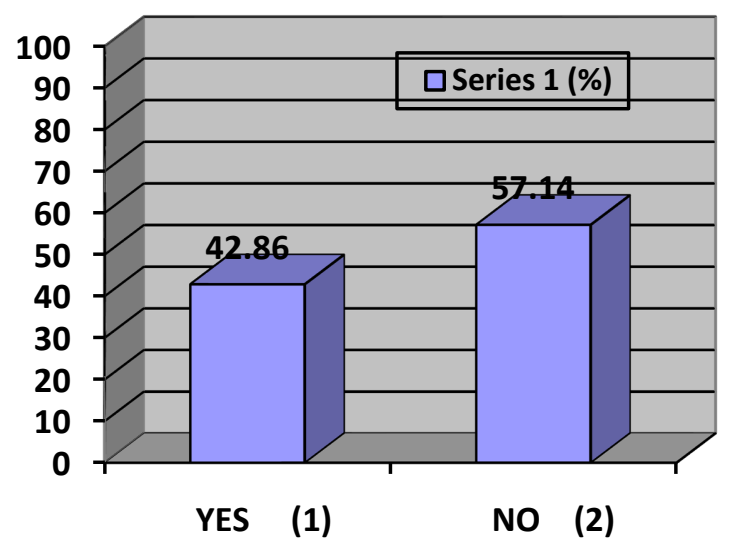

Figure 10. Responses of construction firms that execute projects with HSE personnels or/and trained health personnels. 
Table 8. Responses of construction firms that do routine check-up.

\begin{tabular}{ccc}
\hline YES & NO & TOTAL \\
\hline 13 & 22 & 35 \\
$37.14 \%$ & $62.86 \%$ & $100 \%$ \\
\hline
\end{tabular}

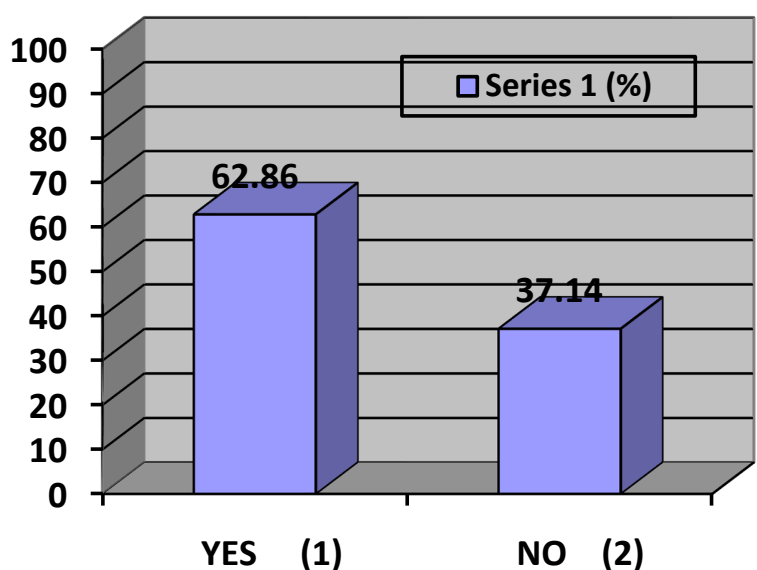

Figure 11. Responses of construction firms having first-aid box.

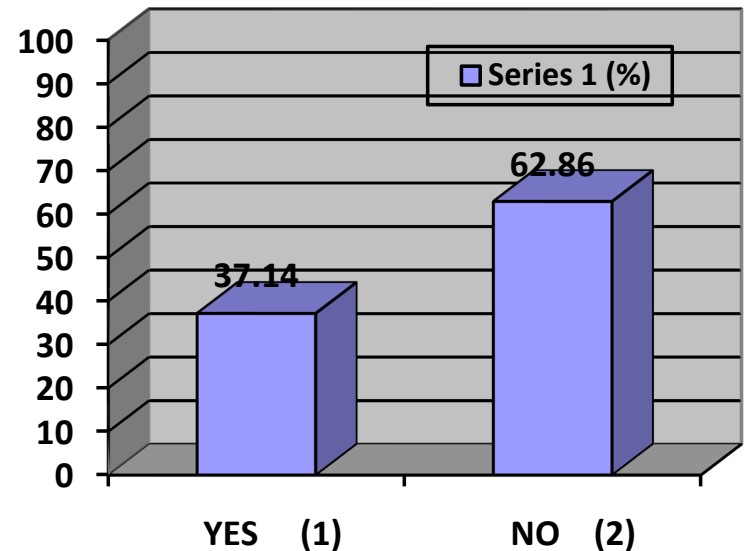

Figure 12. Responses of construction firms that do routine check-up.

\subsection{Responses on Construction Firms Having On-Site Comfort Facilities}

During every infrastructural development on a construction site, there is generally a site house, but there may not always be a comfort room for the workers, particularly in developing nations. In some areas, there are tarven-like toilets or make-shift comfort rooms while others are forced to relieve themselves in the bushes nearby. Table 9 and Figure 13 reveal that 57.14\% of construction firms with on-site toilet/bathroom facilities responded.

\subsection{Responses of Construction Firms with Employees' Insurance Policy}

The principle of insurance policies in the construction industry has struggled to 
Table 9. Responses of construction firms having toilet/bathroom facilities.

\begin{tabular}{ccc}
\hline YES & NO & TOTAL \\
\hline 20 & 15 & 35 \\
$57.14 \%$ & $42.86 \%$ & $100 \%$ \\
\hline
\end{tabular}

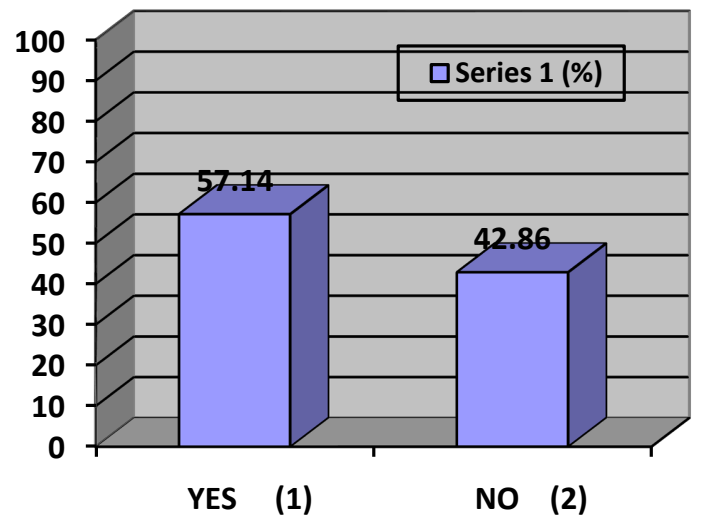

Figure 13. Responses of Construction firms having toilet/bathroom facilities.

acquire traction in emerging countries such as India and Nigeria. Employees should be encouraged to get insurance plans so that they are adequately protected. Table 10 and Figure 14 demonstrate that just $37.14 \%$ of respondents in the construction sector had an employee insurance coverage.

\subsection{Responses of Construction Firms That Recorded Workers Exposed to Biohazards}

From the study, it was important to investigate on the workers exposure to biohazards. In reality, every construction firm is vulnerable to one or more hazards. In the recent COVID19 pandemic, there is an increased level of exposure to both the pandemic and biohazards globally. Table 11 and Figure 15 demonstrate that $42.86 \%$ of construction organisations had personnel who have been exposed to biohazards.

\subsection{Responses of Construction Firms to Have Compensated Hazardous-Affected Employees}

Engineering is a significantly risk-involved profession which does not exclude the risk of pandemics and biohazards, particularly during construction activities. Certain construction activities have higher risk level of hazards, which in-turn progresses into accidents and require that compensations be made to the affected workers. Table 12 and Figure 16 show that responses of construction firms that have compensated affected workers are $54.29 \%$.

\subsection{Responses on Construction Firms to HSE/Standard Legislation}

A Safety Officer must be appointed if there are twenty (20) or more employees, 
Table 10. Responses of construction firms having insurance policies.

\begin{tabular}{ccc}
\hline YES & NO & TOTAL \\
\hline 13 & 22 & 35 \\
$37.14 \%$ & $62.86 \%$ & $100 \%$ \\
\hline
\end{tabular}

Table 11. Responses of construction firms that recorded workers exposed to biohazards.

\begin{tabular}{ccc}
\hline YES & NO & TOTAL \\
\hline 15 & 20 & 35 \\
$42.86 \%$ & $57.14 \%$ & $100 \%$
\end{tabular}

Table 12. Responses of construction firms that compensated affected workers.

\begin{tabular}{ccc}
\hline YES & NO & TOTAL \\
\hline 19 & 16 & 35 \\
$54.29 \%$ & $45.71 \%$ & $100 \%$ \\
\hline
\end{tabular}

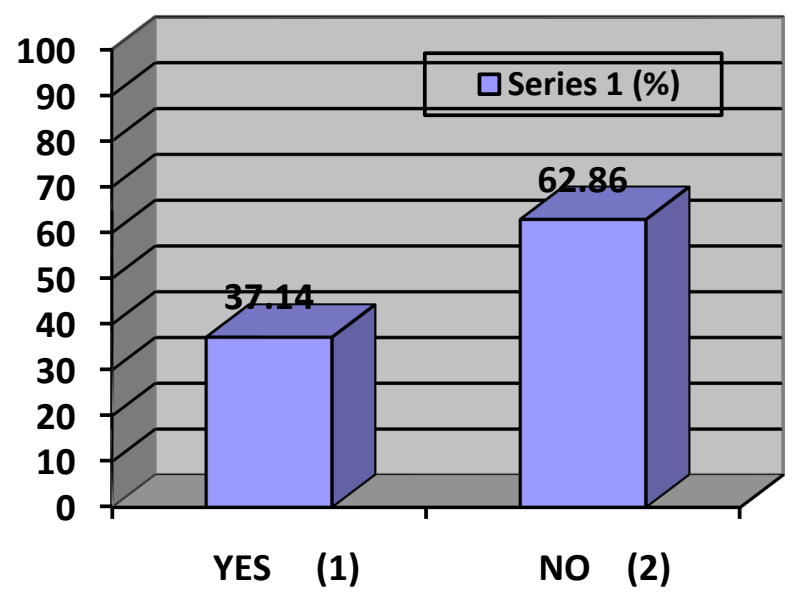

Figure 14. Responses of construction firms that have insurance policies.

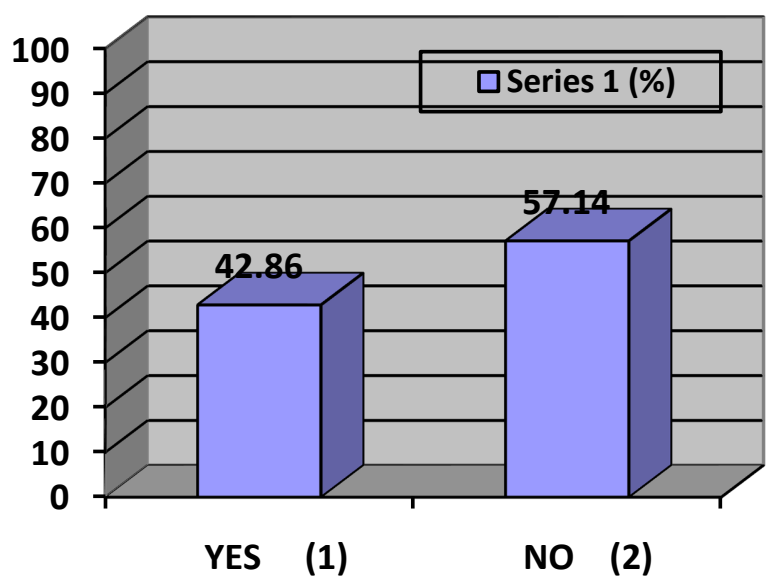

Figure 15. Responses of construction firms that recorded workers exposed to biohazards. 


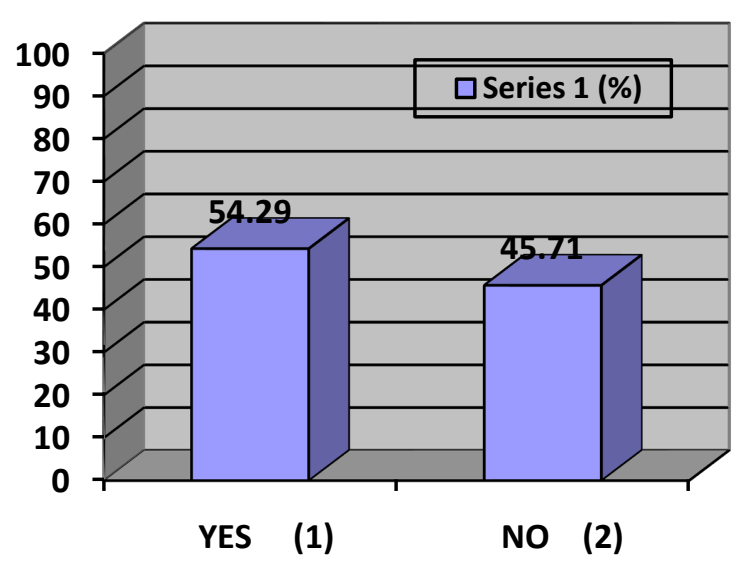

Figure 16. Responses of construction firms that compensated affected workers.

according to the Health and Safety at Work Act of 1974 [80]. Periodic inspections of scaffolding, plant supplies, and the working environment are his job to verify that there are no obvious hazards. He is also in charge of documenting accidents and, if necessary, reporting them to the Head of Management. The majority of construction organisations use standard operating procedures that are in compliance with HSE statutes and other occupational health standards. To avoid accidents or injuries, the working environment of a building site should be kept clean, with the majority of construction organisations sampled responding Yes to following standard guidelines (Table 13 and Figure 17).

\subsection{Responses on Organizing Seminar/Workshops on Pandemics and Biohazards in the Construction Sector}

Sensitization and training of employees is very important in the construction sector. "A man who is not informed is deformed," they say. Since education is dynamic, seminars and workshops should be held to educate and sensitise construction industry employees, clients, and government parastatals about controlling pandemics and biohazards in the construction sector. The seminar/training will comprise health education via movies, toolbox talks, training on the use of personal protective equipment (PPE), PPE selection and replacement, hazard communication, and warning signposts in high-risk regions during a risky engineering exercise. The proposal was well received by the respondents, with $60 \%$ of the responses being Yes, as seen in Table 14 and Figure 18. Typical PPEs used in the control of biohazards and pandemics are seen in Figure 19.

\subsection{Research on Pandemics and Biohazards in the Construction Sector}

The research on pandemics and biohazards in the construction sector has been conducted in this study by comparing data from Scopus obtained in 2021 (in Figure 20(a), Figure 21(a)) and data obtained in 2016 (in Figure 20(b), Figure 21(b)). It shows that with the emergence of CoronaVirus during COVID-19 pandemic, there is an increase in research activities, literature publications and 
Table 13. Responses on construction firms to ensuring standard rules on site.

\begin{tabular}{ccc}
\hline YES & NO & TOTAL \\
\hline 26 & 9 & 35 \\
$74.29 \%$ & $25.71 \%$ & $100 \%$ \\
\hline
\end{tabular}

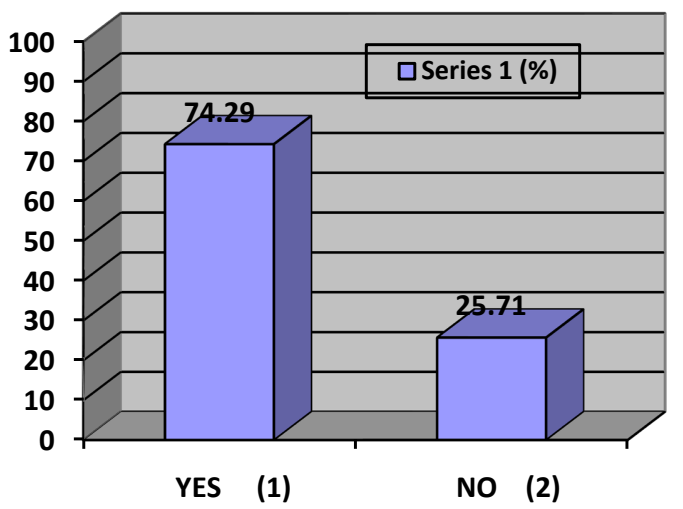

Figure 17. Responses on construction firms to ensuring standard rules on site.

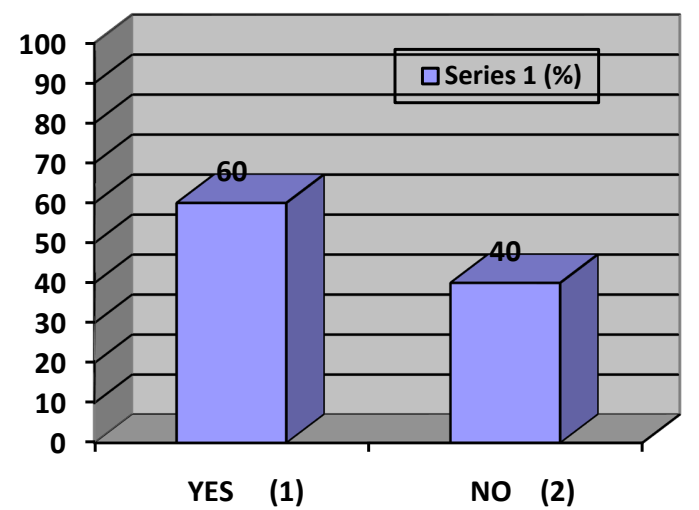

Figure 18. Responses of construction firms that organize Seminars/workshops.

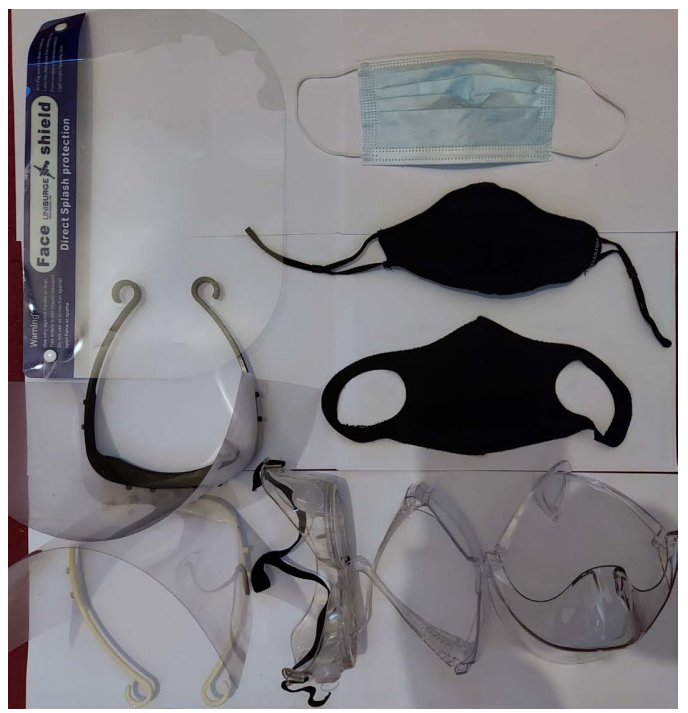

Figure 19. PPEs showing nose masks, eye googles and 3D-printed face shields. 
Table 14. Responses of construction firms to organizing Seminars/workshops.

\begin{tabular}{ccc}
\hline YES & NO & TOTAL \\
\hline 21 & 14 & 35 \\
$60 \%$ & $40 \%$ & $100 \%$ \\
\hline
\end{tabular}
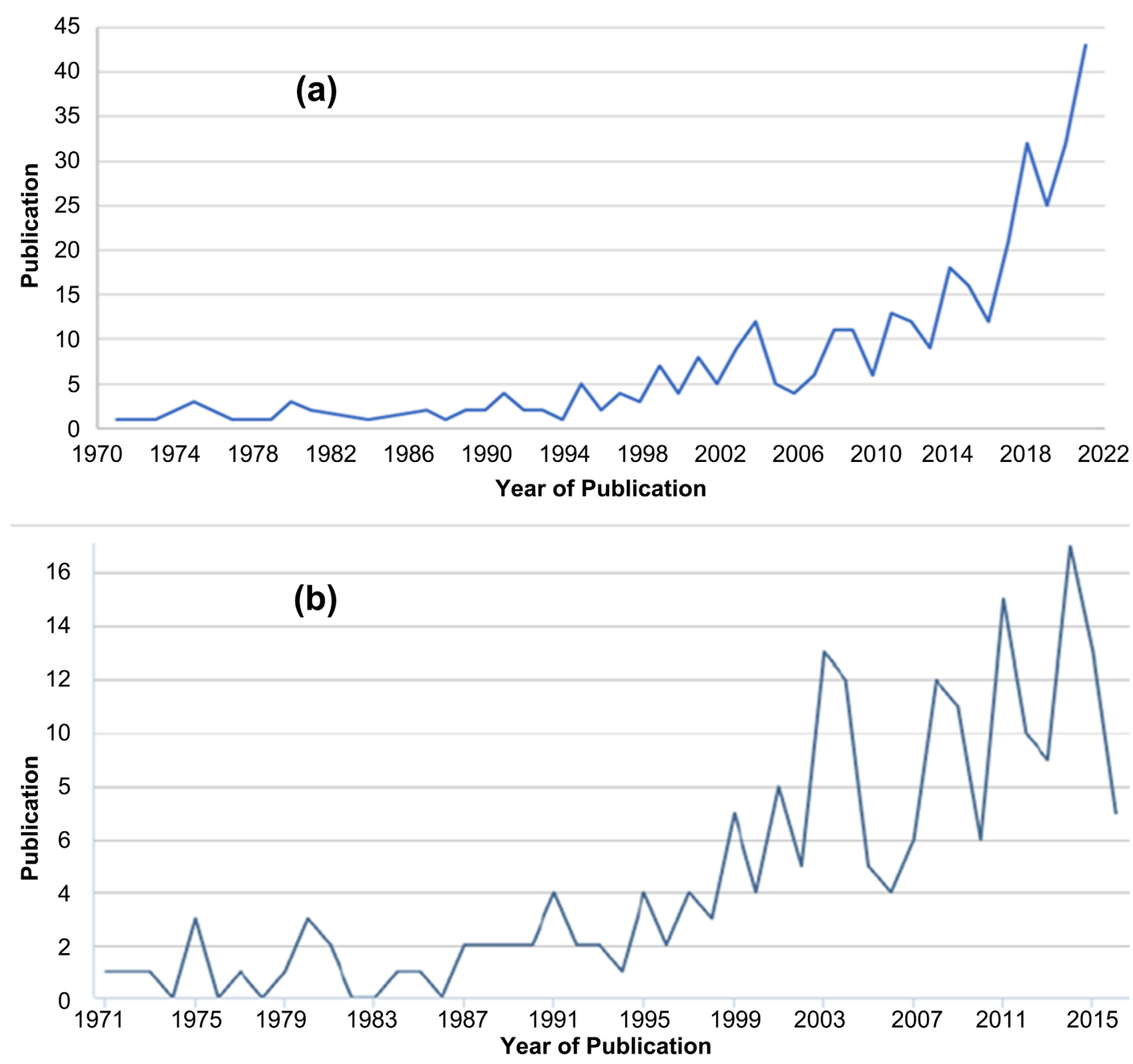

Figure 20. Research on pandemics and biohazards in the construction sector, showing (a) 2021 Scopus data (obtained on $27^{\text {th }}$ December 2021) and (b) 2016 Scopus data (obtained on $25^{\text {th }}$ July 2016).

news reports on pandemics and biohazards. This has particularly increased with more publications on COVID-19 pandemic. In Figure 21(a), Figure 21(b), the research by countries was also conducted and it shows that USA has the highest number of publications in the subject area.

\section{Discussions}

Any engineering job should have muster sites, warning signs, and an effective danger communication approach because safety is paramount. Table 1 and Figure 22 showed that the majority of construction enterprises had warning signs and muster points to control dangers, with $88.57 \%$ of respondents saying "yes". 

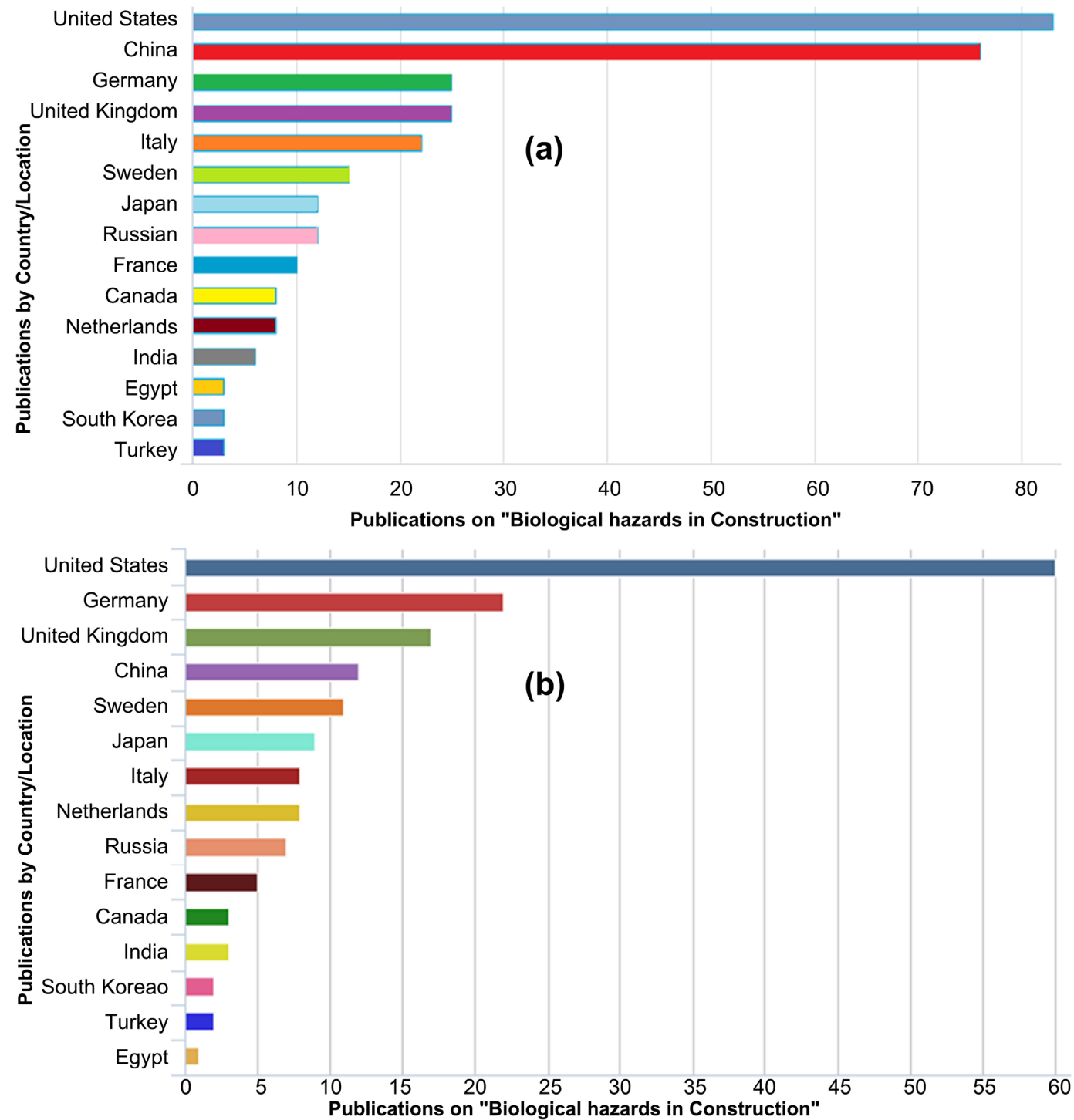

Figure 21. Research on pandemics and biohazards in the construction sector, by countries showing (a) 2021 Scopus data (obtained on $27^{\text {th }}$ December 2021) and (b) 2016 Scopus data (obtained on $25^{\text {th }}$ July 2016).

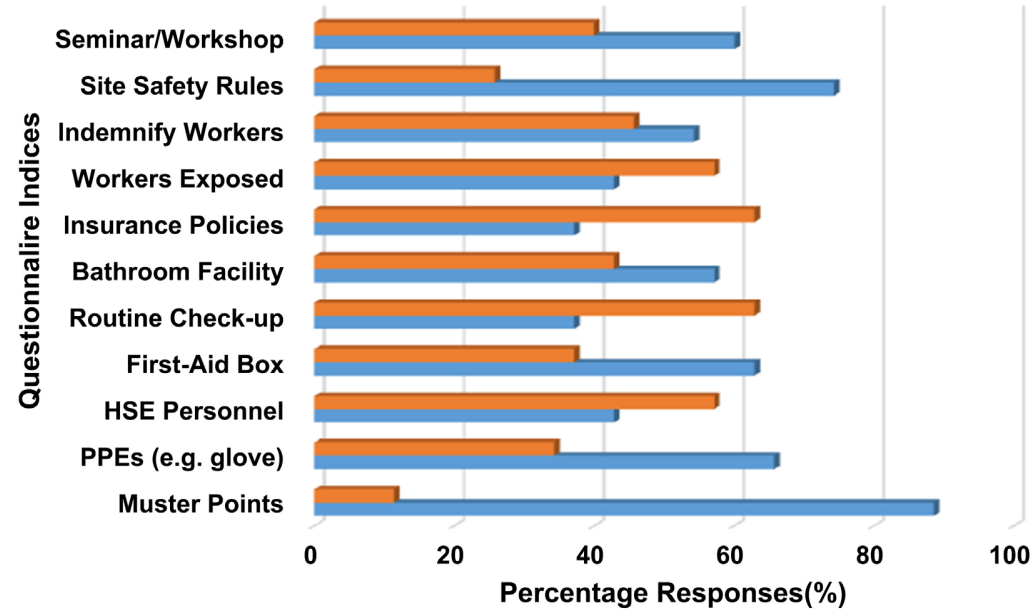

$=$ No (\%)

= Yes $(\%)$

Figure 22. Responses of construction firms that organize Seminars/workshops. 
In the construction industry, the usage of Personal Protective Equipment (PPE) and clothing is critical. Depending on the nature of construction, this may include nasal masks, hand gloves, work aprons, helmets, and goggles. Table 1 also shows that $65.71 \%$ of respondents agreed that PPEs should be used. PPEs used in the control of biohazards and pandemics are seen during the recent COVID19 pandemic. These typical PPEs include face shiels, nose masks and eye googles, as seen in Figure 19. The use of PPEs like face masks have helped in controlling the spread of COV19-19 [22] [23].

Some construction businesses strive to save money by not hiring HSE personnel and trained health personnel such as nurses, putting the lives of their employees in jeopardy. The response to the use of personal protective equipment (PPEs) was $42.86 \%$, which is not good because PPEs should be used more frequently.

In the event of an emergency, the first-aid kit is quite useful. This is also critical on all construction sites, as some biohazards, such as asthma, are fast-acting and life-threatening. As demonstrated in Table 1, construction companies with a first-aid box on site have a response rate of $62.86 \%$. This also demonstrates that not all construction firms have first-aid kits on hand. As the popular saying goes, "health equals riches." Workers should be checked on a regular basis, as this is critical in the construction industry's biohazard control. Table 1 also demonstrates that just $37.14 \%$ of construction firms that undergo routine inspections respond, which should be improved.

During any construction activity on a construction site, there is generally a site house, but there isn't always a comfort room for the workers, thus some are forced to relieve themselves in the bushes nearby. As stated in Table 1, the response rate for construction companies with toilet/bathroom facilities on site is $57.14 \%$. Typical state of construction sites in Ibadan is seen in Figure 23.

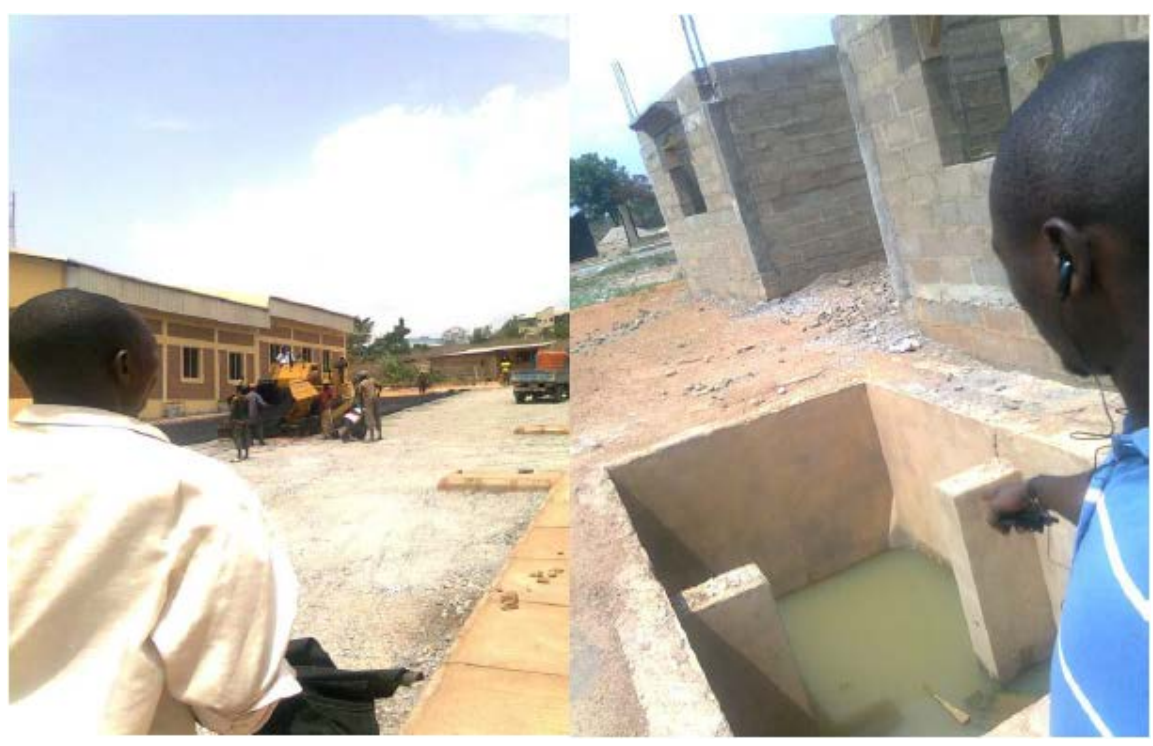

Figure 23. Construction site images in Ibadan showing their states. 
The notion of insurance coverage in the construction industry is not widely understood in developing countries like Nigeria. Employees should be well-insured, therefore insurance coverage should be encouraged. As seen in Table 1, just $37.14 \%$ of employees responded to the insurance policy. Additionally, every construction enterprise is vulnerable to one or more hazards. As demonstrated in Table 1, construction organisations that have had workers exposed to biohazards had a response rate of $42.86 \%$. Engineering is a high-risk profession, and as a result, biological risks can arise during construction. Some of these hazards cause accidents, necessitating compensation for affected employees. According to the analysis, $54.29 \%$ of construction firms have reimbursed impacted workers, as indicated in Table 1.

A Safety Officer must be appointed if there are twenty (20) or more employees, according to the Health and Safety at Work Act of 1974. Periodic inspections of scaffolding, plant supplies, and the working environment are his job to verify that there are no obvious hazards. He is also in charge of documenting accidents and, if necessary, reporting them to the Head of Management. The majority of construction organisations use standard operating procedures that are in compliance with HSE statutes and other occupational health standards. To avoid accidents or injuries, the working environment of a building site should be kept clean, as shown in Table 1, with the majority of construction businesses responding Yes to following standard guidelines. A maxim states that "a man who is not informed is deformed". Since education is dynamic, seminars and workshops should be held to sensitise and educate construction industry employees, clients, and government parastatals about the control of biological risks in the industry. The seminar/training will comprise health education via movies, toolbox talks, training on the use of personal protective equipment (PPE), PPE selection and replacement, hazard communication, and warning signposts in high-risk regions during a risky engineering exercise. The suggestion was favourably received by the respondents, with $60 \%$ of the responses being "Yes", as indicated in Table 1.

\section{Policy Implications}

In view of the current study, the following are hereby recommended for the various stakeholders on the control of biohazards:

\section{1) Government:}

- They should provide a unified legislative and policy framework for occupational health and safety in the sector, as well as ensure that requirements are followed.

- They should give information, guidance, and training on hazards, their control, and prevention; careless employers should be shown that they would attract severe fines, loss of liberty, social stigma, high compensation claims, or loss of licence if they do not follow the rules.

- The World Bank and development organisations have the ability to affect la- 
bour norms and working conditions on construction sites all around the world.

- The construction sector should be inspected on a regular and mandatory basis by the authorised agencies for the safety and general wellbeing of the workers.

\section{2) Employer:}

- They should encourage worker participation in company health and safety policies and risk management systems; due to downsizing and outsourcing, there are now a lot of precarious and informal contractual conditions, so the construction industry is dealing with subcontracting and bogus self-employment.

- They should ensure that suitable standards for preventing blood-borne infections are in place, as well as proper PPE use.

- They should teach each employee how to spot and avoid dangerous situations.

- There should be mandatory employers' liability insurance for all site workers.

- They should participate in workforce capacity training in terms of skills and health and safety, as well as skill certification and prior learning recognition.

- They must be dedicated to and adhere to labour standards, and they must demand that all subcontractors and suppliers observe them.

- All construction sites must include first-aid boxes and trained health personnel and/or HSE personnel for temporary relief in emergency situations.

- A complete personal and family medical history should be provided. Recreational activities, personal habits such as alcohol and cigarette use, nutritional considerations, the existence of chronic diseases, and the use of medicine by construction workers' employers should all be given special consideration.

\section{3) Association of Contractors and Clients:}

- They should make certain that all management and supervisory personnel on their locations have demonstrated expertise in occupational health and safety, as well as management and supervisory abilities.

- They should ensure that all employees have verifiable skill levels, taking into account occupational health and safety.

- They should ensure that all contractors follow labour laws;

- There should be effective communication and coordination between contractors and workers, including training; and

- Tender documents must include provisions for safety, health, and welfare, and all contractors should incorporate these in their cost estimates.

- Each contractor on site should have their occupational health and safety targets audited.

- In the construction business, there should be a regular health promotion programme and safety education training seminars for workers on how to control and prevent biological dangers.

4) Regulatory Bodies, like HSE, OSHA, ILO, CDC and WHO:

- They should promote clean care of equipment and work garments. 
- They should ensure the provision of PPEs.

- They should advise on laundering work clothes and procedures on handling.

- They should promote hand washing hygiene using hand gels and hand sanitisers.

- They should also manage prevention and control of infections.

- They should promote the maintenance of clean and safe work environment.

- They should ensure that social distancing is maintained to control the spread of coronavirus, as seen during the COVID-19 pandemic.

\section{Recommended COVID-19 Protocols}

With respect to the study on biohazards and pandemics, this study presents some recommended COVID-19 protocols for the construction workers. Based on some factors from current guidelines on COVID-19 pandemic, the following advices hold:

- Wearing a nose mask

- Using personal protection measures

- Wearing an eye-protective shield

- Wash your hand with soap frequently

- Avoid hand touching of your nose, mouth and eyes

- Covering the nose and mouth with a tissue when you cough/sneeze

- Good etiquette/manners

- Appropriately dispose the "used tissue paper" after sneezing/coughing

- Wash your hand immediately after sneezing/coughing

- Perform hand hygiene

- Avoid close contact with others

- Avoid sharing PPEs like hard hats or helmets

- Contact precautions such as social distancing of 2 meters

- Avoid group meeting and avoid coming closer with others

- Social distancing when feeling unwell

- Adapting prompt actions by protecting others.

- Surrender to health officials when on notice the symptoms.

- Doing regular COVID-19 tests if symptoms appear.

- Abiding by quarantine, shielding or self-isolate as adviced.

- Workplaces should have relevant COVID-19 notices, door markers and floor markers to show directions, exit signs, $2 \mathrm{~m}$ social distancing signs, etc.

- Workplaces should provide necessary hand hygiene points like hand sanitizers, hand gels, medicated liquid soaps, disposable nose masks, etc.

\section{Conclusions}

Biohazards are intimately linked to environmental and occupational health risks, according to this study on the management of biohazards and pandemics in the Construction Sector. This also demonstrates that while engineers on the job are aware of health and safety regulations (HSE), not all engineers on the job are 
$100 \%$ safety concerned. As a result, all construction enterprises must employ trained health professionals and HSE personnel. Second, biohazards can be avoided through a variety of operations in sectors other than health, infrastructure, energy, and agriculture. Housing, water, sanitation, drainage, transportation, urban development, and energy projects could prevent a high percentage of disability adjusted life year (DALY) loss and the construction industry's mortality rate. In addition, the recent COVID19 pandemic also affected construction work, as well as the living standard and mental health of the construction workers.

One of the outcomes of the present study is that the majority of organisations ensure that basic standards and norms are followed on the job, although not all of them. All sites should also have first-aid and other medical services. Since health is so important in the construction sector, there are health and safety laws and regulations in place, such as the 1974 Health and Safety Act. According to the findings of this study, only roughly two-thirds of the construction companies surveyed employ PPE and protective apparel (PPEs). In the construction sector, personal protective equipment (PPE) such as nose masks, helmets, hand gloves, and work aprons will aid in the control of bio-hazards such as asthma, cancer, and asbestosis. Lessons learnt from the recent COVID19 pandemic include social distancing, proper hand hygiene (the use of hand gels, hand santizers, and hand washing), and going for COVID-19 test if you feel unwell, to protect others. Such acts will ensure a better public health. Finally, industrialised countries have greater health than poor countries, and as a result, they have better control over biohazards and pandemics. Using Ibadan in Nigeria as a case study from a developing country, the study discovered that the percentage of people who have routine check-ups is considerably lower than the percentage of people who don't get routine check-ups, which requires some improvement. In practically every sampled worksite in Ibadan's construction industry, there were also few or no insurance plans. This study also recommends that construction companies are key into having better insurance and health plans for their workers.

\section{Acknowledgements}

The author acknowledges the technical support from Lancaster University Engineering Department, Lancaster, UK and University of Ibadan, Civil Engineering Department, Ibadan, Oyo State. The support of Engr. Daniel Ekadi of Bayelsa State Works Ministry, Nigeria during the conduction of the field study in Ibadan is highly appreciated. The authors also appreciate the respondents on the questionnaire. The authors also appreciate CWEEE for the waiver on the APC charges for this submission.

\section{Funding}

The Department of Engineering, Lancaster University, UK is highly appreciated. In addition, the funding of Overseas Scholarships by Niger Delta Development 
Commission (NDDC) is also appreciated, as well as the support of Standards Organisation of Nigeria (SON), F.C.T Abuja, Nigeria.

\section{Conflicts of Interest}

The authors declare no conflicts of interest regarding the publication of this paper.

\section{References}

[1] Paladini, E., Giovannini, M., Barni, S., Liccioli, G., Sarti, L., Novembre, E. and Mori, F. (2021) Case Report: Self-Administration of Omalizumab in an Adolescent with Severe Asthma during SARS-CoV-2 Infection. Frontiers in Pediatrics, 9, Article ID: 675281. https://doi.org/10.3389/fped.2021.675281

[2] Liu, A.L., Xu, N. and Li, A.J. (2020) COVID-19 with Asthma: A Case Report. World Journal of Clinical Cases, 8, 3355-3364. https://doi.org/10.12998/wjcc.v8.i15.3355

[3] Kenneth, G.E, Maxwell, O. and Amechi, S.C. (2020) COVID-19: A Case with Community-Acquired Pneumonia. Journal of Applied Medical Sciences, 9, 25-27. https://www.researchgate.net/profile/Emwinloghosa-Guobadia/publication/343083 519 COVID-19 A Case with Community-Acquired Pneumonia/links/5f15d2422 99bf1e548c684fc/COVID-19-A-Case-with-Community-Acquired-Pneumonia.pdf

[4] Kenneth, G.E., Maxwell, O. and Amechi, S.C. (2020) COVID-19 Outbreak: An Asthmatic Asymptomatic Case Report. Journal of Applied Medical Sciences, 9, 29-34.

https://www.researchgate.net/publication/343083101 COVID-19 Outbreak An As thmatic Asymptomatic Case Report

[5] Myles, P.S. and Maswime, S. (2020) Mitigating the Risks of Surgery during the COVID-19 Pandemic. The Lancet, 396, 2-3. https://doi.org/10.1016/S0140-6736(20)31256-3

[6] Nepogodiev, D., Bhangu, A., Glasbey, J.C., Li, E., Omar, O.M., Simoes, J.F.F., Abbott, T.E.F, Alser, O., Arnaud, A.P., Bankhead-Kendall, B.K., Breen, K.A., et al. (2020) Mortality and Pulmonary Complications in Patients Undergoing Surgery with Perioperative SARS-CoV-2 Infection: An International Cohort Study. The Lancet, 396, 27-38. https://doi.org/10.1016/S0140-6736(20)31182-X

[7] Yanitsky, O. (2020) A Post-Pandemics Global Uncertainty. Creative Education, 11, 751-759. https://doi.org/10.4236/ce.2020.115054

[8] Daniel, S.J. (2020) Education and the COVID-19 Pandemic. Prospects, 49, 91-96. https://doi.org/10.1007/s11125-020-09464-3

[9] Pfefferbaum, B. and North, C.S. (2020) Mental Health and the Covid-19 Pandemic. The New England Journal of Medicine, 383, 510-512.

https://doi.org/10.1056/NEJMp2008017

[10] Areal, A.G. and Sheppy, B. (2021) A Crisis of Governance-Or an Opportunity? Health Services Insights, 14, 1-5. https://doi.org/10.1177/11786329211033845

[11] Weiss, L. and Thurbon, E. (2021) Explaining Divergent National Responses to Covid-19: An Enhanced State Capacity Framework, New Political Economy. New Political Economy. https://doi.org/10.1080/13563467.2021.1994545

[12] UK.Gov (2020) Covid-19: Health Secretary's statement to Parliament. https://www.gov.uk/government/speeches/covid-19-health-secretarys-statement-toparliament 
[13] DH Pandemic Influenza Preparedness Team (2011) UK influenza Pandemic Preparedness Strategy 2011. Department of Health, London.

[14] USCDC (US Centers for Disease Control and Prevention) (2019) Coronavirus Disease 2019 (Covid-19): Situation Summary.

https://www.cdc.gov/coronavirus/2019-ncov/

[15] WHO (World Health Organization) (2003) Chapter 5. SARS: Lessons from a New Disease. In: World Health Organization, The World Health Report 2003-Shaping the Future, World Health Organization, Geneva, 71-83. https://www.who.int/whr/2003/en/Chapter5.pdf

[16] Amaechi, C.V., Almutlg, A., Amechi, S.C., Oyetunji, A.K., Amaechi, E.C., Kgosiemang, M.I. and Coker, A.O. (2022) Sustainable Alternatives on Plastic Pollution as a Global Environmental Challenge and Implications of COVID-19. Inventions, 7, Under Review.

[17] Xanthos, D. and Tony, R.W. (2017) International Policies to Reduce Plastic Marine Pollution from Single-Use Plastics (Plastic Bags and Microbeads): A Review. Marine Pollution Bulletin, 118, 17-26. https://doi.org/10.1016/j.marpolbul.2017.02.048

[18] Li, W.C., TSE, H.F. and Fok, L. (2016) Plastic Waste in the Marine Environment: A Review of Sources, Occurrence and Effects. Science of the Total Environment, 566-567, 333-349. https://doi.org/10.1016/j.scitotenv.2016.05.084

[19] Hameed, S.A. (2012) Controlling Computers and Electronics Waste: Toward Solving Environmental Problems. International Conference on Computer and Communication Engineering (ICCCE), Kuala Lumpur, 3-5 July 2012, 972-977. https://doi.org/10.1109/ICCCE.2012.6271361

[20] Sigler, M. (2014) The Effects of Plastic Pollution on Aquatic Wildlife: Current Situations and Future Solutions. Water, Air, \& Soil Pollution, 225, Article No. 2184. https://doi.org/10.1007/s11270-014-2184-6

[21] Suresh, S.S., Bonda, S., Mohanty, S. and Nayak, S.K. (2018) A Review on Computer Waste with Its Special Insight to Toxic Elements, Segregation and Recycling Techniques. Process Safety and Environmental Protection, 116, 477-493.

https://doi.org/10.1016/j.psep.2018.03.003

[22] Abboah-Offei, M., Salifu, Y., Adewale, B., Bayuo, J., Ofosu-Poku, R. and Opare-Lokko, E.B.A. (2021) A Rapid Review of the Use of Face Mask in Preventing the Spread of COVID-19. International Journal of Nursing Studies Advances, 3, Article ID: 100013. https://doi.org/10.1016/j.ijnsa.2020.100013

[23] Olukolajo, M.A., Oyetunji, A.K. and Oluleye, I.B. (2022) Covid-19 Protocols: Assessing Construction Site Workers Compliance. Journal of Engineering, Design and Technology, 20, 115-131. https://doi.org/10.1108/JEDT-03-2021-0131

[24] Coker, A.O. and Sridhar, M.K.C. (2010) ICE Manual of Health and Safety in Construction: Controlling Exposure to Biological Hazards. Thomas Telford Limited, London, 135-148.

[25] Amaechi, C.V., Adefuye, E., Oyetunji, A.K., Ja'e, I.A., Adelusi, I., Odijie, A.C. and Wang, F. (2022) Numerical Study on Plastic Strain Distributions and Mechanical Behaviour of a Tube under Bending. Inventions. Open Access Journal, 7, 1-24. https://doi.org/10.3390/inventions7010009

[26] Amaechi, C.V., Chesterton, C., Butler, H.O., Wang, F. and Ye, J. (2021) Review on the Design and Mechanics of Bonded Marine Hoses for Catenary Anchor Leg Mooring (CALM) Buoys. Ocean Engineering, 242, Article ID: 110062. https://doi.org/10.1016/j.oceaneng.2021.110062 
[27] Amaechi, C.V., Chesterton, C., Butler, H.O., Wang, F. and Ye, J. (2021) An Overview on Bonded Marine Hoses for Sustainable Fluid Transfer and (Un)Loading Operations via Floating Offshore Structures (FOS) Journal of Marine Science and Engineering, 9, Article No. 1236. https://doi.org/10.3390/jmse9111236

[28] Davies, M.L. and Masten, S.J. (2004) Principles of Environmental Engineering and Science. McGraw Hill, New York, 169-188.

[29] Amaechi, C.V., Wang, F. and Ye, J. (2021) Mathematical Modelling of Bonded Marine Hoses for Single Point Mooring (SPM) Systems, with Catenary Anchor Leg Mooring (CALM) Buoy Application-A Review. Journal of Marine Science and Engineering, 9, Article No. 1179. https://doi.org/10.3390/jmse9111179

[30] Amaechi, C.V., Gillett, N., Odijie, A.C., Hou, X. and Ye, J. (2019) Composite Risers for Deep Waters Using a Numerical Modelling Approach. Composite Structures, 210, 486-499. https://doi.org/10.1016/j.compstruct.2018.11.057

[31] Amaechi, C.V., Wang, F., Hou, X. and Ye, J. (2019) Strength of Submarine Hoses in Chinese-Lantern Configuration from Hydrodynamic Loads on CALM Buoy. Ocean Engineering, 171, 429-442. https://doi.org/10.1016/j.oceaneng.2018.11.010

[32] Amaechi, C.V., Wang, F. and Ye, J. (2021) Understanding the Fluid-Structure Interaction from Wave Diffraction Forces on CALM Buoys: Numerical and Analytical solutions. Ships and Offshore Structures (In Press).

[33] Statista (2020) Exemplary Use of 3D Printing to Provide Medical Supplies during Coronavirus (COVID-19) Pandemic in 2020.

https://www.statista.com/statistics/1107198/covid-19-3d-printing-medical-supplies

[34] Novak, J.I. and Loy, J. (2020) A Quantitative Analysis of 3D Printed Face Shields and Masks during COVID-19 [Version 1; Peer Review: 2 Approved]. Emerald Open Research, 2, Article No. 42. https://doi.org/10.35241/emeraldopenres.13815.1

[35] Wierzbicki, J., Nowacki, M., Chrzanowska, M., Matkowski, R., Ziętek, M., Nowacka, K., Maciejczyk, A. and Pawlak-Adamska, E. (2020) Additive Manufacturing Technologies Enabling Rapid and Interventional Production of Protective Face Shields and Masks during the COVID-19 Pandemic. Advances in Clinical and Experimental Medicine, 29, 1021-1028.

[36] Celik, H.K., Kose, O., Ulmeanu, M.-E., Rennie, A.E.W., Abram, T.N. and Akinci, I. (2020) Design and Additive Manufacturing of a Medical Face Shield for Healthcare Workers Battling Coronavirus (COVID-19) International Journal of Bioprinting, 6 , Article No. 286.

[37] Clifton, W., Damon, A. and Martin, A.K (2020) Considerations and Cautions for Three-Dimensional-Printed Personal Protective Equipment in the COVID-19 Crisis. 3D Printing and Additive Manufacturing, 1, 97-99.

https://doi.org/10.1089/3dp.2020.0101

[38] Kumar, A., Kumar, N., Kumar, A., Chowdhry, B.K. and Sinha, A.K. (2020) How a Portable Negative Pressure Incubator for COVID-19 Was Created with Minor Modifications. Acta Paediatrica, 109, 2423-2424. https://doi.org/10.1111/apa.15521

[39] Davenport, F. (2021, May 20) Life Sciences Startup Moves to Dedicated Incubator Lab to Focus on COVID-19. Imperial College London, London.

https://www.imperial.ac.uk/news/221753/life-sciences-startup-moves-dedicated-inc ubator/

[40] Tarfaoui, M., Nachtane, M., Goda, I., Qureshi, Y. and Benyahia, H. (2020) 3D Printing to Support the Shortage in Personal Protective Equipment Caused by COVID-19 Pandemic. Materials, 13, Article No. 3339. 
https://doi.org/10.3390/ma13153339

[41] Zuniga, J.M. and Cortes, A. (2020) The Role of AM and Antimicrobial Polymers in the COVID-19 Pandemic. Expert Review of Medical Devices, 17, 477-481. https://doi.org/10.1080/17434440.2020.1756771

[42] Manero, A., Smith, P., Koontz, A., Dombrowski, M., Sparkman, J., Courbin, D. and Chi, A. (2020) Leveraging 3D Printing Capacity in Times of Crisis: Recommendations for COVID-19 Distributed Manufacturing for Medical Equipment Rapid Response. International Journal of Environmental Research and Public Health, 17, Article No. 4634. https://doi.org/10.3390/ijerph17134634

[43] Khan, R.S. and Rehman, I.U. (2020) Spectroscopy as a Tool for Detection and Monitoring of Coronavirus (COVID-19) Expert Review of Molecular Diagnostics, 20, 647-649. https://doi.org/10.1080/14737159.2020.1766968

[44] Khan, R.S., Rehman, H.U. and Rehman, I.U. (2020) Saliva for the Diagnosis of COVID-19. Applied Spectroscopy Reviews, 55, 805-809. https://doi.org/10.1080/05704928.2020.1809442

[45] Herat, S. and Agamuthu, P. (2012) E-waste: A Problem or an Opportunity? Review of Issues, Challenges and Solutions in Asian Countries. Waste Management \& Research, 30, 1113-1129. https://doi.org/10.1177/0734242X12453378

[46] Talvitie, J., Mikola, A., Koistinen, A. and Setälä, O., (2017) Solutions to Microplastic Pollution-Removal of Microplastics from Wastewater Effluent with Advanced Wastewater Treatment Technologies. Water Research, 123, 401-407. https://doi.org/10.1016/j.watres.2017.07.005

[47] Kohl, C.A. and Gomes, L.P. (2018) Physical and Chemical Characterization and Recycling Potential of Desktop Computer Waste, without Screen. Journal of Cleaner Production, 184, 1041-1051. https://doi.org/10.1016/j.jclepro.2018.02.221

[48] Amaechi, C.V., Odijie, C., Sotayo, A., Wang, F., Hou, X. and Ye, J. (2019) Recycling of Renewable Composite Materials in the Offshore Industry. Encyclopedia of Renewable and Sustainable Materials, 2, 583-613. https://doi.org/10.1016/B978-0-12-803581-8.11445-6

[49] Amaechi, C.V., Odijie, C., Etim, O. and Ye, J. (2019) Economic Aspects of Fiber Reinforced Polymer Composite Recycling. Encyclopedia of Renewable and Sustainable Materials, 2, 377-397. https://doi.org/10.1016/B978-0-12-803581-8.10738-6

[50] Eboh, L.O. and Onohwakpor, A.E.O. (2002) Occupational Health Hazards and Safety Measures in Delta Glass Plc Ughelli, Delta State. Nigerian School Health Journal, 14, 95-103.

[51] Essenberg, L.O (1998) The Occupational Safety and Health Problem in Developing Nations. Olubumi Publishers, Nigeria.

[52] Seagle, E.F. (1998) The Occupational Safety and Health Act of 1970 and the Department of Health, Education and Welfare. American Journal of Public Health, 64, 411-414. https://doi.org/10.2105/AJPH.62.3.411

[53] Adeniyi, J.A. (2002) Occupational Health and Safety: Concepts, Objectives and Relevance. Nigerian School Health Journal, 14, 192-198.

[54] Adeogun, J.O. and Idowu, B.B. (2002) On-the-Job Safety Assessment in Food Processing Industry: A Case Study of Nestle Nigeria Plc. Nigerian School Health Journal, 14, 18-23.

[55] Agunwamba, J.C. and Afangideh, C.B. (2004) Minimization of Environmental Pollution and Hazards in the Oil and Gas Industry through Training in Safety Practices. Journal of Applied Science, Engineering and Technology, 4, 11-17. 
https://doi.org/10.4314/jaset.v4i2.38274

[56] Amaechi, C.V. (2016) Health, Safety and Biohazards in Construction: How Safe Is the Work Place? Risks and Hazards in Our Environment. LAP LAMBERT Academic Publishing, Germany. https://eprints.lancs.ac.uk/id/eprint/136434/

[57] Amaechi, C.V. (2010) The Control of Biological Hazards in Construction Industry: A Case Study of Ibadan. MSc Dissertation, Civil Engineering Department, University of Ibadan, Ibadan.

[58] Amunega, S.B. (2002) Occupational Hazards in Odo-Okun Sawmill in Ilorin West, L.G.A of Kwara State: Causes and Prevention. Nigerian School Health Journal, 14, 25-33.

[59] HSE (2022) Construction Frequently Asked Questions (FAQ)-Biological Hazards. Health and Safety Executive, UK. https://www.hse.gov.uk/construction/faq-biological.htm

[60] Centers for Disease Control and Protection (CDC) Bioterrorism: Preparation and Planning for Bioterrorism Emergencies. U.S. Department of Health \& Human Services, Atlanta, Georgia, USA. https://emergency.cdc.gov/bioterrorism/prep.asp

[61] OSHATrain (2022) Course 850 Health Hazards in Construction: BIOLOGICAL HEALTH HAZARDS. OSHA Academy, Geigle Safety Group, Inc., Beaverton, OR USA. https://www.oshatrain.org/courses/mods/850m3.html

[62] Michael, S.M. (1997) The Biological Exposure Indices: A Key Component in Protecting Workers from Toxic Chemicals. Environmental Health Perspectives, 105, 105-115. https://doi.org/10.1289/ehp.97105s1105

[63] NIOSH (National Institute for Occupational Safety and Health) (2002) Guidance for Protecting Building Environments from Airborne Chemical, Biological or Radiological Attacks. DHHS Publication No. 2002-139, National Institute for Occupational Safety and Health, Washington DC.

[64] ISO (2018) ISO 45001:2018 Occupational Health and Safety Management Systems: Requirements with Guidance for Use. International Organization for Standardization (ISO), Geneva, Switzerland. https://www.iso.org/standard/63787.html

[65] World Health Organization (n.d.) Occupational Health. http://www.who.int/topics/occupational health/en/

[66] Occupational Safety and Health Administration. http://www.osha.gov

[67] Okediran, Y.A. (2007) Making Environmental Protection Law Enforcement Everybody's Business in Nigeria: Dimensions of Environmental Problems in Nigeria. Davidson Press, Ibadan, 116-126.

[68] CACC (Construction Agency Coordination Committee) (2004) Occupational Health and Safety Management Systems Guidelines. 4th Edition, Construction Agency Coordination Committee. New South Wales.

[69] CDC (Centre for Disease Control and Prevention) (1993) The National Institute for Occupational Safety and Health (NIOSH). https://www.cdc.gov/niosh

[70] Foster, A. (1995) The Effects of Work on Health. Work and Health: An Introduction to Occupational Healthcare. M. Bamford, Champman Hall, London.

[71] Onyemaechi, C.N. and William, H.S. (2009) Modern Environmental Health Hazards: A Public Health Issue of Increasing Significance in Africa Modern Environmental Health Hazards: A Public Health Issue of Increasing Significance in Africa. Environmental Health Perspectives, 117, 863-870. https://doi.org/10.1289/ehp.0800126 
[72] Pattron, D.D. (2009) Potential Hazards and Proactive Solutions in the Construction Industry-Construction Industry, Idea Marketers.

http://www.onlinemarketers.com

[73] Paul, T.C.H., Leonard, S.L., Graham, P., Geoffrey, H.P. and Lewis, L.S. (1999) Comparative Hazards of Chrysotile Asbestos and Its Substitutes: A European Perspective. Environmental Health Perspectives, 107, 607-611. https://doi.org/10.1289/ehp.99107607

[74] Ta, L., Gosa, L. and Nathanson, D.A. (2019) Biosafety and Biohazards: Understanding Biosafety Levels and Meeting Safety Requirements of a Biobank. Methods in Molecular Biology, 1897, 213-225. https://doi.org/10.1007/978-1-4939-8935-5 19

[75] HSE (2013) Control of Substances Hazardous to Health (Sixth Edition): The Control of Substances Hazardous to Health Regulations 2002. Approved Code of Practice and Guidance. L5, 6th Edition. Health and Safety Executive (HSE), London, UK, 1-100. https://www.hse.gov.uk/pubns/priced/15.pdf

[76] OSHA (2015) Construction Industry Digest. Report Number OSHA 2202-09R 2015. Occupational Safety and Health Administration (OSHA), US Department of Labour, Washington DC, USA.

https://www.osha.gov/sites/default/files/publications/osha2202.pdf

[77] Das, S. and Kataria, V.K. (2010) Bioterrorism: A Public Health Perspective. Medical Journal Armed Forces India, 66, 255-260. https://doi.org/10.1016/S0377-1237(10)80051-6

[78] Falomo, A.A. (1997) Government's Action in Environmental Protection in Nigeria: Dimensions of Environmental Problems in Nigeria. Davidson Press, Ibadan, 102-113.

[79] Gyi, D.E., Haslam, R.A. and Gibb, A.G.F. (1998) Case Studies of Occupational Health Management in the Engineering Construction Industry. Occupational Medicine, 48, 263-271. https://doi.org/10.1093/occmed/48.4.263

[80] HSE (Health and Safety Executive) (1974) Health and Safety at Work Act or HASAWA. https://www.hse.gov.uk/legislation/hswa.htm 